\title{
Strawberry Breeding Work of the U.S. Department of Agriculture
}

\author{
F.J. Lawrence ${ }^{1}$ \\ National Clonal Germplasm Repository, Corvallis, OR 97333 \\ G.J. Galletta ${ }^{2}$ \\ U.S. Department of Agriculture Fruit Laboratory, Beltsville, MD 20705 \\ D.H. Scott $^{3}$ \\ 4404 Howard Road, Beltsville, MD 20705
}

The U.S. Department of Agriculture (USDA) strawberry breeding program is in its 69th consecutive year. Although not the oldest program in the United States, it is the longest continuous program. The USDA strawberry breeding program began in 1920, with George M. Darrow in charge. Darrow had made a survey from 1914 to 1917 of the commercial strawberry regions of the United States, and found some serious deficiencies in the quality of berries for the various markets (Darrow et al., 1933).

He outlined more than 30 characteristics for evaluation, but picked three specific ones for immediate work: 1) Development of a superior dessert berry for the eastern states; 2) development of satisfactory canning types; 3 ) development of cultivars for preserving by freezing.

More than 130 strawberry cultivars and 20 selections of Fragaria species were used in the breeding work during the 1920 s, and 44 of these parents were of European origin (Darrow et al., 1934). Thousands of seedlings were evaluated, and, from this early work, several cultivars were named (Darrow, 1937). Probably the two most important were 'Blakemore' and 'Fairfax'. 'Blakemore' rapidly became a leading cultivar, and set the standard for firmness that permitted successful long-distance shipment of fruit. 'Blakemore' had wide adaptability in the southern and south-central U.S. regions and is still grown commercially in some areas. 'Blakemore', 'Fairfax', and other USDA selections such as 253, 543, and 634 from this early work became widely used as parents in other breeding programs (Darrow, 1966). This is especially true of 'Fairfax' because of its excellent fruit quality and leaf spot resistance (Darrow, 1962).

While the program was under the direction of George Darrow, formal cooperative work began with state experiment stations at North Carolina and Oregon in 1928, and Maryland in 1937. Other informal cooperative work has since been initiated with New Jersey, New York, and Massachusetts. Also, during the period of 1920 to 1940, studies were made on sterility, fertility, inflorescence types, and response to light. Darrow $(1937,1966)$ provided excellent summaries of this early USDA and other public and private strawberry breeding.

Incorporation of the flavor and aroma of the diploid $(2 \mathrm{x}=14)$ $F$. vesca $L$. into the cultivated strawberry $F$. xananassa Duch. was also investigated. Tetraploid $F$. vesca selections were developed (Derman and Darrow, 1938) and used in additional crosses by Scott (1951). Decaploids developed from this work were fertile and could be intercrossed to produce fertile seedlings with the characteristic $F$. vesca aroma; however, these have not played a role in the development of modem-day cultivars.

In 1932, Strawberry breeding was moved from Glenn Dale, Md., to Beltsville, Md., where it continues today. A root disease became evident in several states in the 1930s and was also found on the Beltsville station grounds. This disease, identified as Phytophthora fragariae Hickman (red stele), became serious in the East and $\mathrm{Pa}$ -

${ }^{1}$ Research Horticulturist.

${ }^{2}$ Research Geneticist.

${ }^{3}$ Principal Research Horticulturist, USDA (Retired). cific Northwest. Screenings for resistance were first carried out in infested fields. However, Waldo (1953), who joined the USDA strawberry program in 1926 and was in charge of breeding at Corvallis, Ore., since 1932, showed that young seedlings could be screened in benches of infested soil in greenhouses. This method greatly increased the number of seedlings that could be tested. Resistance to red stele became a primary objective of the USDA breeding program and 'Temple' was released in 1943 as the first cultivar bred with resistance to the disease. Development of cultivars resistant to $P$. fragariae has necessitated a great deal of research because of the presence of physiologic races of the organism (Converse and Scott, 1962; Scott et al., 1984). The history, breeding, and inheritance studies of red stele have been discussed in several papers (Scott et al., 1962; Scott and Lawrence, 1975) and in a more extensive review by Scott et al. (1984).

Important sources of resistance to the disease have come from $F$. chiloensis (L.) Duch. clones collected by Waldo (Scott et al., 1984); these clones are identified as 'Del Norte' and 'Yaquina' (Converse, 1970). Later, two distinct clones of 'Yacquina' were identified, A and B. Yaquina A has been one of the primary clones for resistance in the race testing (Converse, 1970).

Because the development of cultivars resistant to red stele has been a primary objective of the USDA program, various resistant cultivars have been introduced, such as 'Surecrop', 'Midway', 'Sunrise', 'Guardian', 'Earliglow', and, more recently, 'Scott', 'Allstar', 'Lester', and 'Lateglow'. In the Pacific Northwest, Waldo introduced 'Siletz' in 1955, the first red stele-resistant strawberry for this region. Since then, two other important red stele-resistant cultivars-Hood and Benton-have come from the cooperative USDA-Oregon State strawberry breeding program. Additionally, the first day-neutral cultivars with multiple resistance to red stele, 'Tristar' and 'Tribute', were released from Beltsville in 1981 (Galletta et al., 1981).

Virus tolerance is essential in the Pacific Northwest, where strawberry plantings are maintained for several years and there are large populations of aphid vectors along with the virus complex. 'Marshall', for many years the leading cultivar in the Pacific Northwest, was extremely virus-susceptible and has been replaced by tolerant cultivars such as 'Totem', 'Benton', and 'Siletz'.

The germplasm for the virus tolerance in cultivars such as 'Siletz' and 'Benton' was developed by Waldo's program for selection of vigorous clones in the field under highly infective conditions. The basis of tolerance is primarily from $F$. chiloensis (L.) Duch. (Miller and Waldo, 1959). In the eastern United States, virus tolerance has not been a factor in the breeding work, although the USDA was instrumental in introducing virus-free stocks into the nursery program and in maintaining these Stocks (Galletta et al., 1981). Demaree and Marcus found that most strawberry stocks were infected with virus that weakened plants (Demaree and Marcus, 1951). Introduction of virus-free stocks by the USDA stabilized the cultivar situation, an important factor in strawberry breeding and for the commercial strawberry industry.

Screening selections and cultivars for resistance to verticillium wilt [ Verticillium albo-atrum (Reinke \& Berth.) and $V$. dahliae Kleb.] was initiated by Scott in the late 1950s (Varney et al., 1959) 
by using field plots infested with the organism. More recently, seedlings, selections, and cultivars have been rated for resistance using mycelium suspensions and sand benches similar to red stele evaluations (Galletta et al., 1981). One of the latest USDA releases, 'Lateglow', is highly resistant to verticillium wilt.

The USDA Small Fruit Research Laboratory, Poplarville, Miss., and cooperators in North Carolina, Florida, and Louisiana are screening strawberry seedlings for anthracnose (Colletotrichum sp.) resistance. Anthracnose, a destructive disease of the southern and south-central United States, attacks the plant and fruit, and several species of the fungi may be involved (Maas, 1984). A screening method developed at the USDA laboratory in Mississippi has identified two clones, MSUS 73 and 74, as strongly resistant to anthracnose crown rot with yields equal to the standard cultivars. They also have superior internal fruit color. Additionally, several North Carolina selections, such as 'NC 3874' and 'NC 3892', have resistance to both anthracnose and red stele.

In the eastern United States, leaf spot [ Mycosphaerella fragariae (Tul.) Lindau], leaf scorch, [ Diplocarpon earliana (Eli. \& Ev.) Wolf], and leaf blight [ Phomopsis obscurans (Ell \& Ev.) Sutton] can be very destructive diseases and resistance is a specific objective in the cooperative work with Maryland, North Carolina, and, until the station closed in 1972, at the USDA-Southern Illinois University Experiment Station at Carbondale. 'Blakemore' and 'Fairfax' inherited resistance to foliage diseases from 'Howard 17' and have passed it on to their progeny (parrow, 1966). Selection for resistance has continued. The work at Carbondale began in 1959 with R.C. Blake in charge and resulted in the release of 'Delite', resistant to both leaf spot and leaf blight. Other USDA cultivars, such as 'Surecrop', 'Earliglow', 'Earlibelle', 'Scott', and 'Lester', show considerable resistance to these foliage diseases.

Strawberry breeding work began at the Cheyenne Horticulture Field Station, Cheyenne, Wyo., in 1937 with LiRoy Powers as the principal investigator. One of the main emphases of the work was studying crosses between the winter-hardy native Rocky Mountain strawberry ( $F$. virginiana glauca Staudt) and cultivars (Powers, 1945). More winter hardiness was needed in the cultivated types. Work was continued by G. Howard until the station was closed in 1975. Eight cultivars were introduced from this work, the last one being 'Fort Laramie', a hardy everbearing type. 'Ogalalla', also winter hardy, was introduced in 1956, and is still grown in limited areas where low temperatures are encountered.

A labor crisis in the 1960s in the Pacific Northwest spurred interest in breeding strawberry cultivars for machine harvest. A portion of the cooperative USDA-Oregon State Experiment Station project was directed toward this goal, and included in the work was the Oregon State Univ. Agriculture Engineering Dept., which built the harvesting and capping equipment. Selecting strawberries with an erect fruiting habit, ripening most of the fruit at one time, and easy capping-all important characters for machine harvest-is possible because of the variability that exists in the available strawberry germplasm. Inheritance patterns for simultaneous ripening of the fruit showed that early season parents, such as 'Sunrise', could provide progeny with a high percentage of the crop ripe at one time (Lawrence et al., 1975). Semi-erect and easy-capping (calyx easily removed) types could also be derived by using parents such as 'Hood', 'Benton', and other selections from the Pacific Northwest and California. Additionally, selections that have $>80 \%$ of the fruit ripe at one time and with the easy-cap character could also have good processing qualities (Lawrence et al., 197.5). The cultivar Linn was introduced in 1975 as a machine-harvest processing berry; however, commercial machine harvest failed to materialize and 'Linn' lost favor because it does not hold berry size as plants age and is too tart for the fresh market. At present, machine harvest of strawberries for the commercial processing industry remains at an experimental stage in the Pacific Northwest.

Four federal locations were involved in the past 69 years of strawberry breeding, but only one, Beltsville, remains as a USDA lo- cation with an active program. Carbondale closed in 1972, Cheyenne in 1975, and the work at Corvallis is being redirected. After Darrow retired in 1957, Scott assumed the work at Beltsville until he retired in 1975. Arlen Draper was the strawberry breeder until 1977, when G.J. Galletta became the principal breeder. Galletta has continued an extensive cooperative program with various states, including Wisconsin, Maryland, North Carolina, Florida, New York, New Jersey, Missouri, Maine, and Minnesota.

The USDA breeding work has some promising selections from this cooperative work-selections such as 'NC 3874' and 'NC3892' for the coastal plain, North Carolina; 'MDUS 4787', 'MDUS 5122', 'MDUS 5130', 'NJ 8123-5', and 'NJ 8219-2 for the Mid-Atlantic and Midwest; and, for the North, hardy selections 'MNUS 99', MNUS 52', MNUS 37', NY 113', WIUS 8284', and WI 8289'. New day-neutral selections ('EB 411', 'EB 457', and 'EB 460') with multiple disease resistance also are promising.

The USDA strawberry breeding program started with clear, definable objectives to originate cultivars adapted to environmental conditions existing in the different regions and still maintains these objectives.

\section{Literature Cited}

Converse, R.H. 1970. Occurrence of Phytophthora fragariae race A-10 in California. Plant Dis. Rptr. 54:969-971.

Converse, R.H. and D.H. Scott. 1962. Physiologic specialization in Phytophthora fragariae. Phytopathology 52:802-807.

Darrow, G.M. 1937. Breeding small fruits; strawberry improvement. U.S. Dept. of Agr. Yrbk. of Agr., 1937. p. 445-495.

Darrow, G.M. 1962. Fairfax strawberry--its origin and use in breeding. Fruit Var. J. 16:23-25.

Darrow, G.M. 1966. The strawberry-history, breeding, and physiology. Holt, Rinehart, and Winston, New York.

Darrow, G.M., G.F. Waldo, and C.E. Schuster. 1933. Twelve years of strawberry breeding: J. Hered. 24:391-402.

Darrow, G.M., G.F. Waldo, C.E. Schuster, and B.S. Pickett. 1934. Twelve years of strawberry breeding, II. J. Hered. 25:450-462.

Demaree, J.B. and C.P. Marcus. 1951. Virus diseases of strawberries in the United States, with special reference to distribution, indexing, and insect vectors in the east. Plant Dis. Rptr. 35:527-537.

Dermen, H. and G.M. Darrow. 1938. Colchicine induced tetraploid and 16-ploid strawberries. Proc. Amer. Soc. Hort. Sci. 36:300-301.

Galleita, G.J., A.D. Draper, and D.H. Scott. 1981. The U.S. Department of Agriculture strawberry breeding program. HortScience 16:743-746.

Lawrence, F.J., L.W. Martin, and G.W. Varseveld. 1975. Strawberry breeding and evaluation for mechanical harvesting. Ore. St. Agr. Expt. Sta. Tech. Bul. 131.

Maas, J.L. 1984. Compendium of strawberry diseases. Amer. Pathol. Soc., St. Paul, Minn.

Miller, P.W. and G.F. Waldo. 1959. The virus tolerance of Fragaria chiloensis compared with the Marshall variety. Plant Dis. Rptr. 43:11301131.

Powers, L.R. 1945. Strawberry breeding studies involving crosses between the cultivated varieties ( $\times$ Fragaria ananassa $)$ and the native Rocky Mountain strawberry ( F. ovalis. ) J. Agr. Res. 70:95-122.

Scott, D.H. 1951. Cytological studies on polyploids derived from tetraploid Fragaria vesca and cultivated strawberries. Genetics 36:311-331.

Scott, D.H. 1962. Breeding and improvement of the strawberry in the United States of America-A review. Hort. Res. 2:35-55.

Scott, D.H., G.E. Stembridge, and R.H. Converse. 1962. Breeding Fragaria for resistance to red stele root rot ( Phytophthora fragariae Hickman). Proc. XVIth Intl. Hort. Congr., 1962. p. 92-98.

Scott, D.H. and F.J. Lawrence. 1975. Strawberries, p. 71-97. In: J. Janick and J.N. Moore (eds.). Advances in fruit breeding, Purdue University Press, West Lafayette, Ind.

Scott, D.H., A.D. Draper, and G.J. Galletta. 1984. Breeding strawberries for red stele resistance. Plant Breeding Rev. 2:195-214.

Varney, E.H., J.N. Moore, and D.H. Scott. 1959. Field resistance of various strawberry varieties and selections to Verticillium. Plant Dis. Rptr. $43 \times 567-569$

Waldo, G.F. 1953. Sources of red stele root disease resistance in breeding strawberries in Oregon. Plant Dis. Rptr. 37:236-242. 